\title{
Welfare transformations and expectations of sameness. Living on the margins in Denmark
}

\section{Camilla Merrild*}

The Research Unit for General Practice, Department of Public Health

Aarhus University

Email: chm@dcm.aau.dk

\section{Rikke Sand Andersen}

Department of Anthropology and Research Unit for General Practice

Aarhus University

Email: rsa@ph.au.dk

${ }^{*}$ corresponding author

\begin{abstract}
In Denmark, as in other welfare societies worldwide, the organisation and ideology of welfare are becoming increasingly influenced by neoliberal ideas. In practice, this means that the original intention behind the provision of social support, which was grounded in the notion of social responsibility, is gradually being pushed aside by notions of responsibilisation, with concepts such as deservingness and work ethic appearing to dominate the discourse. Based on long-term fieldwork and interviews conducted with socially disadvantaged Danes living on social security, this article engages with the current debates regarding responsibility and highlights some of the challenges arising from living a life that diverges from what has been termed Danish 'in-between middleclassness'. We argue that the divergence between the promise of welfare, the current landscape of political regulation and expectations of individual responsibility leads to new forms of uncertainty, as experienced by those who depend on the services provided by the welfare state. One implication of this is that welfare seems to increasingly be tied to an agenda of sameness, whereby citizenship stems less from a imagination of sameness than from an expectation of sameness.
\end{abstract}


Keywords: Denmark, Sameness, Social Class, Social Inequality, The Welfare State

\section{The Changing Politics of Responsibilities in Welfare Societies}

This article explores how neoliberal transformations of the welfare state impinge upon the lives of people who depend on social security. This is achieved by attending to the suffering experienced by those who struggle with social problems and poor health, and who are dependent upon the Danish welfare state. The promulgation of the Social Reform Act in 1933 is often portrayed as the beginning of what eventually became known as the Danish welfare state, a socially informed project based on notions of universalism and solidarity, which necessitated the provision of a broad range of welfare initiatives such as free education and health care for all, subsidised childcare and medication, and care for the sick and elderly (Jöhncke, 2011). These welfare benefits are all funded by the redistribution of financial resources via taxation, which is organised according to the principle that those who earn the most must pay the most tax. Hence, in terms of rights and opportunities, the tax system also serves as a form of financial redistribution based on principles of equality. Simply put, this means that the institutional arrangements range from standardised welfare services, which all Danes come into contact with at various points in their lives, to more specialised interventions and support directed towards those who fall outside the mainstream with regards to their life trajectory or expected norms (Langer \& Højlund, 2011). In Denmark, as in other welfare societies worldwide, the organisation and ideology of welfare are, however, becoming increasingly influenced by neoliberal ideas (Bruun et al., 2016). Neoliberalism is often described as a theory of political economic practices that proposes human wellbeing to be best advanced by liberating individual entrepreneurial freedoms and skills within an institutional framework characterised by strong private property rights, free markets and free trade, and where state interventions in the markets must be kept to a bare minimum (Harvey, 2007, pp. 2-3). However, in many parts of Scandinavia, neoliberal reforms are increasingly underpinned by cultural values such as individual responsibility and productivity, while ongoing changes seem to unfold through strengthening some of the existing state foundations (Mik-Meyer \& Villadsen, 2013). The role of states in what Chomsky (1998) referred to as 'the introduction of neoliberalism into the global order' ( $p$. $19)$ has been widely discussed by historians, philosophers and social scientists 
(Chomsky, 1998; Pedersen, 2011). ${ }^{1}$ In our analysis, we draw on Bourdieu's (1999) conceptualisation of the state as a 'splintered space' that acts in competing and contradictory ways depending on who initiates actions on behalf of the state. Bourdieu (1998, pp. 1-10) eloquently described these state contradictions with reference to 'the left' and 'the right' hand of the state. In a recent paper by Waquant (2009), the right hand is defined as representing the masculine and punitive side of the state, which is given to behavioural regulation, while the left hand is said to represent the feminine side, which is given to socially supportive policies and interventions. This perspective embraces the duality of many state institutions, which both provide a range of social or material support and also punish citizens for their failure to comply with social norms concerning personal responsibility. Additionally, we draw on the work of Norwegian anthropologist Marianne Gullestad (1992), who has written extensively about the Scandinavian imagination of sameness. We suggest that the transformation of the welfare state under neoliberal rule means that it is no longer built on an imagination of sameness (Gullestad, 1992, 2001), but rather on an expectation of sameness. Here, we infer that the downplaying of differences by the prevailing egalitarian ethos has contributed to the welfare state's disregard of the very different realities that Danes experience in terms of the provision of welfare, with social security arguably being one of the most significant markers of this difference.

Recent studies exploring transformations of the Danish welfare system have contributed substantial research into the interface between the state and 'the making subjects' (e.g. Bruun et al., 2016; Jöhncke, 2011; Lien et al., 2001; MikMeyer \& Villadsen, 2013). Focusing on social security and welfare-to-work programmes, Järvinen and Mik-Meyer (2003) and Mik-Meyer and Villadsen (2013) described in great detail how welfare state expectations concretise in imperative personal development schemes, which aim to shift social security recipients towards greater self-support. Likewise, Rytter (2018) vividly pointed out how integration policies and practices are strengthened by the introduction of welfare state programmes that aim to make refugees more independent through the provision of job training. Focusing on another group of Danes outside the workforce, Ludvigsen (2016) illustrated how the welfare state subjects elderly citizens to various demands and requirements to remain fit and healthy, as well as to proactively maintain a good health status for as long as possible, by inserting behavioural demands (such as exercising, taking the

\footnotetext{
${ }^{1}$ For an interesting Danish case, see Bruun (2018).
} 
correct medication, and so on) into their everyday lives (see also Katz [2000] and Lamb [2014] for a similar point). Taken together, these studies demonstrate how, despite substantial changes in public spending, Danish neoliberalism does not solely work against the state in the guise of cutbacks and austerity, but also through established welfare institutions. In fact, the authors illustrate how the allocation of social security in Denmark is increasingly subject to the strict regulation of who, when and how welfare can be allocated. Indeed, the provision of social security is increasingly articulated in the language of rights and responsibilities, which is 'embedded in a discourse of individual responsibility' (Dencker-Larsen \& Lundberg, 2016, p. 4). For instance, the social benefit reform that was implemented in 2013 reads, 'social security recipients must work for their benefits, and if they are not available for work, there must be sanctions (...). Hence there must be implemented a more goal-oriented and efficient availability and sanction system' (Beskæftigelesministeriet, 2013, pp. 6-7, our translation). In addition to the substantial reductions in social security for the poorest people in Denmark, these sanctions are directed towards people outside the workforce. In practice, this means that, in order to receive social security, people are judged as either 'job equipped' (jobparat) or 'activity equipped' (aktivitetsparat). If a social security recipient is considered to be job equipped, then s/he has to actively apply for a wide range of available jobs and to document her/his job-seeking activity. If social security recipients remain unemployed for an extended period, they are expected to participate in welfareto-work programmes, which can involve job training and activation assigned by social services. For those categorised as being activity equipped, active job seeking is not required, although such social security recipients are expected to participate in an individual development process aimed at moving them closer to employment, which involves working in close cooperation with one or more social workers. If applying for an early disability retirement pension, an individual's physical and mental ability to work are tested and they must also be medically verified, again in close cooperation with a social worker. Four times a year, all social security recipients are required to attend a meeting at their local job centre, where their progress is discussed. If their obligations are judged to not have been met, their social security will be reduced based on the severity of the offence. The case of social security exemplifies how neoliberalism in Denmark appears to be integrated into, and somehow merged with, the influential state that still maintains the power to regulate its citizens, despite political calls for state refraction and a minimal state. At the same time, however, traditional welfare ideologies emphasising similarities, equality and universalism hover in the background, highlighting current tensions between welfare 
principles and practices and embodying the contradictions so vividly described by both Bourdieu $(1998,1999)$ and Waquant (2009).

In the remainder of this article, we will argue that the divergence between the promise of welfare, the current landscape of political regulation and expectations of individual responsibility leads to new forms of uncertainty, as experienced by those who depend on the welfare state. Inspired by recent discussions of social suffering and its social or institutional embeddedness (e.g. Wilkinson \& Kleinman, 2016), we draw attention to the dual role played by insistent regulation and highlight how it may add to the suffering of those dependent upon social security. We do so by presenting three portraits of people and situations that exemplify some of these complexities and contradictions of the system. Moreover, they offer insights into what it means to be dependent on, and to live in the midst of, contemporary forms of 'welfare'. We also consider how the constant demands of job training and personal development, which are intended to enable independent living, correspond to the central governance of the welfare state. The increased rationalisation inherent in social life, which Weber (1920) foresaw in The Protestant Ethic and the Spirit of Capitalism, adds cumulatively to the suffering of marginalised citizens. The portraits we present illustrate the points made by Weber (1920) nearly 100 years ago, which have been more recently explored in contemporary settings by Wilkinson and Kleinman (2016), namely how suffering in welfare societies must be viewed with reference to the regulatory powers of welfare institutions and the ways in which they impinge upon people's lives and execute their power. However, we will first offer a few comments on our chosen methodology.

\section{A Note on the Methodology}

This article is based on two interconnected ethnographic research projects conducted among low-income Danes during the period 2012-2017. Both research projects involved fieldwork and both explored social differences in terms of health. ${ }^{2}$ The first research project was designed as a communitybased, comparative ethnographic fieldwork, and it focused on social differences in care-seeking practices (Merrild, 2015). The fieldwork that informed the project was conducted in two socially distinct communities, and Merrild engaged with twelve key informants and their families over a period of twelve months. Six of

2 Both projects were conducted by Merrild in close cooperation with Andersen. 
the key informants lived in a socially disadvantaged neighbourhood, while six lived in an area that was characterised by high social status. The present article draws on data revolving around the six informants who lived in the socially disadvantaged neighbourhood, who were recruited from the local community house. The second research project was designed as a longitudinal interview study, and it was conducted among socially disadvantaged people suffering from cancer (Merrild and Andersen, 2019). The aim of the second project was to explore the interactions between marginalised citizens and the health-care system. Ten people participated in this second research project, and they were recruited through local general practice clinics. The primary research methods used were interviews, along with field visits, over a period of three to six months. The informants who we include in the present article were all outside the labour force and all lived on social security, which meant that they all had a low level of income. They were all highly dependent on a variety of welfare services, ranging from standardised arrangements, such as early retirement pension schemes, to more specialised and supportive interventions, such as individualised supportive and administrative supervision (i.e. housing assistance or participation in welfare-to-work schemes).

Through the chosen methods of participant observation (Atkinson, 2015) and ethnographic interviews (Spradley, 1979), Merrild sought to develop an insight into the informants' everyday lives, by participating in social situations with their family and friends, as well as by spending time at their homes, talking, drinking coffee and passing the time with computer games, puzzles, and games. She also participated in a variety of everyday activities, such as job training, gymnastics and grocery shopping. One of the most significant contributions of the participant observation approach is the ability to gain an understanding of how everyday life is lived and, thereby, to develop an insight into what it is like to be poor, sick and suffering in an affluent welfare state. Immediately after every field visit and interview, substantial field notes were written, with the material produced taking the form of descriptions of people, situations, experiences and contexts. Merrild engaged with some informants on a weekly basis and with others on a monthly basis, depending on the particular situation of each informant. Although participant observation is unique in terms of facilitating an in-depth understanding of what shapes and influences people's lives, it can also sometimes be a difficult method to apply. In both research projects, many of the informants were people who lived much of their lives at home and without many social interactions, which sometimes made participating in and observing everyday life difficult, since not much really happened. Moreover, the informants in the second project were sick and 
suffering, which meant that the original intention of following them in their everyday lives had to be changed to a methodology of field visits and repeated interviews. Despite these challenges and the constant ethical considerations, the decision to follow the informants over time and on a regular basis was grounded in the view that, when seeking to understand what living life in particular situations or contexts is like, a much more in-depth understanding can be gained by actually being there and developing a sense of what is really going on (Atkinson, 2015).

In addition to participant observation, Merrild also interviewed all the key informants several times. The ethnographic interviews were semi-structured and revolved around the informants' life story (growing up, previous working life, family life, etc.), everyday life (social and current family situation) and health and illness status. All the interviews were transcribed verbatim and the transcripts, along with the field notes, were reread several times to discover common themes across the two related projects. Subsequently, the data derived from the two research projects were pooled and thematically coded using NVivo 11. The data were handled in accordance with the General Data Protection Regulation (GDPR) and treated with both confidentiality and care. All the informants were provided with written information about the projects before they gave written informed consent to participate, and it was explained to them that they could withdraw from the research at any time and without penalty. The informants in the portraits presented below have been anonymised. The persons in the first and third portrait participated in the first research project, while Jasmin, in the second portrait, participated in the second research project. However, the analysis rests on the combined data from both research projects.

\section{Portrait 1: The Insecurity of Social Security - 'You get worried, you know what I mean?'}

Most of the people Merrild worked with had experienced long-term unemployment and their lives were characterised by broken relationships, growing up surrounded by various forms of substance abuse, chronic illness, dropping out of school and poverty. For some, these conditions were inherited, in the sense that their lives replicated the social conditions that their families had experienced for generations. For others, their difficult situations had arisen due to a combination of unfortunate circumstances and occurrences in their lives, such as family feuds, failed relationships, serious chronic illness or simply being unable to cope with stress and pressure any longer. It seems fair to question how notions such as personal development and responsibility 
resonate in lives that are often fraught with suffering, disease, and social and family-related problems.

Johnny, a 58-year-old pipe fitter, is one of Merrild's key informants. For the past ten years he has been living on social security. He lost his job at a slaughterhouse due to cutbacks and, almost simultaneously, he began suffering from recurring venereal sores and erysipelas, which drove him into a deep depression that ultimately culminated in long-term unemployment and extended periods of sickness. For the first few years, he was so depressed and overweight that he never left his house. He just sat on his brown velour couch for months on end. He did not talk to anyone and he never went outside. It is hard to imagine Johnny like that now; he is doing much better. He is usually cheerful and he jokes with everybody, his round, bear-like figure, greying hair and bushy beard giving him a friendly, kind, almost grandfather-like, appearance. Johnny likes to talk, and when Merrild visits him in his onebedroom apartment, where the curtains are always drawn and the table is covered by jigsaw puzzles with thousands of pieces (every visit, there is a new puzzle), they sit on the brown velour sofa and chat, for hours. Having recovered from his depression and with his erysipelas attacks now substantially reduced, he is starting to get back on his feet and is currently participating in yet another clarification process initiated by social services. This means that he is attending a number of job training sessions to test his physical and mental capabilities, as well as to determine whether he is eligible for either flexible employment (subsidised by the state, which means working for reduced hours on tasks adapted to his ability to work) or, alternatively, an early disability retirement pension. However, Johnny never knows when his erysipelas will break out and, over the past four to five months, he has had monthly attacks. Therefore, he has been sick a lot and unable to go to work. When he does go to work, he is exhausted from having to stand up for long periods at a time. He worries that 'they keep pushing him' and that not being able to do what is expected of him will send him back into a depression. It is not because Johnny does not want to work. When he describes his previous working life, he almost lights up with pride, and he seems to enjoy the job training, which mainly consists of packing various goods into boxes and doing other odd jobs assigned to him by social services. He vividly describes a particular job where they managed to repack even large shipments with tight deadlines. 'We had to repack ten thousand boxes', he tells me, 'and we did it'. He is engaged in the workplace, even though it is only temporary, and he makes various suggestions about changing some of their procedures to help render the workflow more efficient and manageable. For instance, he suggested that they introduce morning meetings to review the 
day's tasks so that the workers could be prepared for what needed to be done. He naturally assumes the role of the team leader, urging the others to get the job done. The week after he tells me about his innovative ideas for the workplace, he falls ill with a fever and his venereal sores and erysipelas flare up again, leaving him bedbound for more than a week. Johnny is sick and most of the time he feels unwell. Just getting to his job training, which is located less than a kilometre away from his apartment, is difficult and it takes him more than half an hour to walk because he has to stop to rest several times. When Johnny talks about his situation, he is clearly agitated about how 'they' (his social worker, the social security system as a whole) impinge on his everyday life by means of obligations (testing of his ability to work), surveillance (monitoring of his physical status through medical examinations and records) and control (of his daily comings and goings). 'They' seem to be more concerned with checking and keeping an eye on him than with providing him with social support. In fact, the informants often described experiences akin what has been coined as the clientisation of recipients of social security (Järvinen \& Mik-Meyer, 2003), which refers to how social services are increasingly experienced as a system of control shaped by mistrust and surveillance. Like Johnny, the other informants also used a hostile tone when discussing social services, and there was a general sense of powerlessness against the interference of the welfare state. Statements such as 'It's not up to me to decide that' or 'They don't listen to me anyway' imply a loss of control over their lives as well as a failure to live up to the moral obligation of contributing to the common good and upholding the welfare society. In Johnny's own words:

I know that I used to make good money, and I really did earn a lot. I don't anymore, and I can feel that. But really, I still think that ... Well, it's when you start living on social security. It should just be for a brief period because you ... it can make you sick ... You have to think about it all the time. You get stressed and you also get worried, you know what I mean?

\section{Faring Well in (Work) Life}

Despite Johnny's obvious agitation and contempt, he has very clear expectations as to what he wants and needs from the welfare system. Somehow, he seems to be caught in the complex interplay of what Mik-Meyer and Villadsen (2013) described as ambivalent and paradoxical governance of the welfare state, where the ideals of personal responsibility and reduced social benefits are combined with micromanagement techniques of power, which have been introduced into various state institutions. The issue of clientisation and the unequal patron-client relationship between the social security recipient and the state thus seems to work against not only the principles of individual 
responsibility, but also the idea of reciprocity between the state and its subjects, by articulating and imposing extensive governance strategies. For instance, social security recipients are obliged to complete prescribed job training as a means of earning the right to receive social security, and this is presented as an opportunity for personal development rather than a case of micromanagement and coercion. There is a strikingly unequal patron-client relationship between the welfare state and its beneficiaries, which places the social security recipient in a subordinate, dependent role (Järvinen \& MikMeyer, 2003) that is maintained by the power to sanction and control through financial means, but also through the provision of assistance and support with personal and professional development. Mik-Meyer and Villadsen (2013), who have extensively studied the interactions between the Danish welfare state and its beneficiaries, assert that:

\begin{abstract}
in the welfare provision of today, power takes both the shape of juridical sanctions and of attractive offers for self-development. When state institutions punish criminals, remove children at risk, or enforce sanctions upon welfare recipients the question of power is imminently urgent. It is less readily evident that power is at stake when institutions educate, counsel or 'empower' citizens (p. 3).
\end{abstract}

The constant testing and assessment of people's ability to work and hold down a job so as to determine the extent to which they are able to take care of themselves is accompanied by a constant pressure to develop new skills and qualifications, which, it is hoped, will eventually move them out of dependency. While the importance of enabling people to contribute to the common good initially appears to support political reform movements, pushing the central values of progressivity and the ability to manage life independently (Bruun et al., 2016; Järvinen \& Mik-Meyer, 2003; Pedersen, 2011), regimes of surveillance and distrust seem to directly counter such aims. Thus, what actually constitutes 'the welfare society' is configured not just through processes of mutual identification and trust between a country's inhabitants, but also by culturally defined mutual interests in certain economic and practical arrangements, such as participation in the workforce serving as an important marker of inclusion (Bruun et al., 2016, pp. 27-28; Jöhncke, 2011, p. 35). The right to receive welfare benefits under neoliberal rule increasingly comes with obligations and duties, which specify how to fit in and align with the progressivity of the state. Reflecting on welfare and its significance in shaping what we consider to be 'the good life', Langer and Højlund (2011) suggested that we think of welfare as the forms of assistance and benefits that allow the public to 'fare well' through life. Johnny's story certainly reminds us that 'welfare institutions are designed not only to take care of people's basic needs but also 
to enable them to fare well in accordance with the dominant norms of society' (Gulløv, 2011, p. 22). Following a similar line of thought, Wilkinson and Kleinman (2016) recently argued that:

social suffering cannot be studied in the absence of committing to social interventions. Such interventions, however, not only may relieve suffering; they can increase it (intentionally or unintentionally), and they can also fail. This landscape of implementation of programs and services is also the landscape of social suffering; it is fraught with moral difficulty and almost inevitably courts opposition and conflict (p. 16).

Welfare is indeed both cultural and moral. How people's lives are enabled or supported in any given system indicates the subtle as well as the explicit expectations as to how they are supposed to orchestrate their lives. As explored above, this often leads to conflict, not just in terms of relational conflict, but also conflicts between possibilities, options and selves. Johnny and his peers do not think of themselves as relevant objects of mistrust or surveillance; rather, the need to manage social security and dependency in this climate only adds to their suffering. Now, let us turn to a further explanation of this issue in another portrait, which introduces us to Jasmin.

\section{Portrait 2: The Temporality of Life on Social Security - 'I Am Protected for Another Few Months'}

Since leaving school after the tenth grade, Jasmin has been living on social security. Her parents divorced when she was a teenager, after which she moved around a lot. Her serious mental health issues started when she was around 18 years old. They were set in motion by a family tragedy that involved the murder of a close relative, which led to a series of depressive episodes. She has never been able to shake the tragedy, and she has been on and off sick leave ever since. Now 27, she lives alone in a small apartment overlooking a lake. Painstakingly clean and tidy, the apartment is decorated in shades of white and rose, which stands in stark contrast the dirty, ramshackle stairwell outside. Her apartment offers no indication of her troubled life. Last year, she was diagnosed with cervical cancer, which prompted yet another breakdown. The thought of never being able to have children left her feeling like she just did not want to live any more. Now, however, she has finished her chemo therapy and is slowly getting better. She is almost back on her feet, slowly regaining her energy and not drinking anymore. Once her energy fully returns, Jasmin is planning to start training as a chauffeur. She wants to drive people who are ill to their hospital appointments. She loves to drive and, due to her own experience of being ill and having to go back and forth for hospital appointments and treatments, she feels that she may be able to help others. She reasons, 'That way I can make a 
life for myself, where I am not dependent on anyone else, and where I can do something I enjoy'. She has a plan and, when she eloquently describes it in detail, it does not seem like the first time she has had to explain her future goals and ideas for progression, not to mention how she expects to achieve them.

Jasmin could be described as 'an experienced social security recipient'. However, fulfilling all the obligations and requirements of the welfare system has become increasingly difficult. Jasmin is worried about losing her social security benefits because social services want to send her to job training, but right now she just does not have the energy to attend. It is very stressful for her, since they will cut off her money. 'But I am protected for another few months [due to the cancer], I know that', she tells me. Jasmin is clearly not feeling well, and it is difficult for social services to assess her ability to work. During the period that Merrild met with Jasmin, she became increasingly unstable. She forgot about appointments with her GP, with Merrild and with community services. Sometimes, when Merrild showed up at her apartment, she was not there. Sometimes, she opened the door dressed in her nightwear, looking dazed and confused, woken by the intrusion, even though it was past midday. She appeared to have sunk into a depression, isolating herself, refusing to answer her phone or open her door. She had broken down again, as had happened so many times before.

Like many of the other people living with long-term unemployment and social security that Merrild worked with, Jasmin was trying to deal with the knocks and bruises that life had given her. The similarities in the stories that Merrild was told, in the ways people's troubles were recounted, and in the circularity of the patterns described were striking. The stories all seemed to narrate a neverending string of social, mental and physical challenges, and they revolved around experiences of distrust and feelings of powerlessness in their dealings with, and dependency on, social services. These frustrations may be grounded in the sense that what was considered a right to welfare could be taken away from them. Jasmin was trying to orient herself towards the future, to make plans and find direction in life, and thereby to live up to the neoliberal ideals of proactivity by taking responsibility for her life. Having been dependent of welfare services for her entire life, however, she has, in a sense, been brought up by the welfare state, which has done everything it could to enable her to fare well. She has experienced the transition from care and support during her younger years to the increasing demands of personal development, independency and making a living on her own. In the face of this, her cancer has become a sanctuary, offering protection from the constant assessment of her ability to 
participate in the workforce - at least for a while. Her suffering is social, brought on by a range of unfortunate situations, including her troubled adolescence, her life on social security, her psychological problems and the lack of fit between her circumstances and her expectations of the welfare state (and vice versa).

\section{Middle-Class Denmark and the Work Ethic}

Jasmin has lived a difficult life. It is a life that does not seem to reverberate with obligations of personal development and expectations of independency and making a contribution to the common good. She has always been dependent on the welfare state, although it is becoming increasingly difficult for her to fit in with the current conception of that welfare state, which seems to increasingly align with the Danish middle-class, white-picket-fence ideal, often jokingly epitomised as consisting of a house, a dog and a station wagon. Although generally described with an ironic ring to it, the connotations of a white-picketfence life encapsulate the ideals and expectations surrounding typical Danish family life, where being able to buy a house, raise children and drive a nice car is highly valued, and where life is lived based on values such as thrift, hard work, honesty and aspiration. Danes have thus been characterised as having an 'inbetween middle-class consciousness', considering themselves to have neither too much nor too little and that standing out from the norm, whether financially or otherwise, is embarrassing, if not inappropriate (Faber, 2008, p. 100; Linnet, 2011 , p. 25). In a sense, middle-classness can be described as going about one's daily business, taking care of one's family, contributing to upholding the welfare society, 'aiming for the ordinary' (Offersen, 2016) and maintaining a strong work ethic (Dencker-Larsen \& Lundberg, 2016).

According to statistics, however, socioeconomic middle-classness is not unequivocal. For instance, although a recent survey study conducted in a major Danish city showed that three out of four people categorised themselves as belonging to the middle class, this resonated poorly with the sociodemographic profile of the city (Faber et al., 2012). Likewise, a nationwide study identified significant socio-demographic diversity in areas such as income and education, and it suggested that approximately $25 \%$ of the adult Danish population aged 18 to 59 years belong to the middle class, $10 \%$ to the upper class and $66 \%$ to the lower or working class (Olsen et al., 2012). Hence, although a selfperception of in-between middle-classness dominate the Danish model of social relationships when viewed from a socioeconomic perspective, social diversity still exists in terms of finances, occupation, health and geography (Diderichsen et al., 2011; Faber et al., 2012; Olsen et al., 2012). It may thus be argued that 
middle-classness refers more to a norm (Jenkins, 2012), a sentiment or an imagination, as well as to a style of interaction and social organisation that downplays differences and underlines similarities of interest (Gullestad, 1992, 2001), than to the dominance of an actual social class. The lives of the informants Merrild worked with all differed substantially, but common to all of them was the fact that they seemed far removed from the middle-classness described above. However, Johnny's and Jasmin's situations demonstrate how the welfare state intervenes in people's lives in ways that ignore how some lives diverge from the ideals of progressiveness, where people are expected to 'fare well' according to what has been described elsewhere as the middle-class ideal (e.g. Faber, 2008; Faber et al., 2012; Linnet, 2011). With reference to the work of Norwegian anthropologist Marianne Gullestad (1992), who has written extensively about the Scandinavian imagination of sameness, we suggest that in contemporary Danish (and perhaps Scandinavian) welfare societies, citizenship is no longer built on an imagination of sameness $(1992,2001)$, but rather on an expectation of sameness. By this, we infer that the downplaying of differences by the prevailing egalitarian ethos has contributed to the welfare society's disregard of the highly different realities that Danes experience in terms of the provision of welfare, with social security arguably being a significant marker of such differences. However, the next and final portrait will indicate how these different realities are contested by those living on social security, which suggests that imaginations and expectations of sameness are complex and multifaceted.

\section{Portrait 3: Unemployment and Marginalisation}

The grey buildings look tired and worn. Facades partially painted in various pastel colours half-heartedly serve to break up the monotony, although the shades of grey encircling the parking lot remain overwhelming. The windows reveal nothing about who lives inside the apartments, since the curtains are mainly drawn or the blinds shut. One building houses the community house, where many of the residents who are unemployed gather during the day to hang out, chat or play cards. There are always people there, from around 10 a.m. until late in the evening. For those who do not work, it is a good place to meet. There is always someone to talk to. Merrild often hung out with her key informants at the community house, which was a central field site during her fieldwork. On this particular day, Johnny is there, together with Brian, Fanny, George, Kirk and a few other people. Sitting in a bright room with windows overlooking the parking lot, the mood is somewhat sombre today, with Johnny and his neighbour, Brian, seeming particularly annoyed. The meters on the 
buildings' heaters are being read, and they are talking about how annoying it is that they have to sit around and wait for the janitor. Johnny grumbles about how he is not going to sit at home and wait around, 'If l'd been at work I wouldn't have had to sit around, would I?' he asks rhetorically. He adds, 'I wouldn't have been at home; I would have been at work. I told the janitor that I was going to the community house to play cards and I just couldn't sit around and wait'. They all agree that they cannot simply be expected to sit around at home and wait. They also have things to do, and there is a vivid exchange of opinions about how they have important things in their lives too. This is just one small, everyday example that illustrates how the informants attempt to reconfigure their social situation according to mainstream middle-class society, where they, for instance, do not have time to sit at home and wait for the janitor. Reconfigurations of this nature can be seen as ways of managing marginalisation and suffering within a public climate in Denmark characterised by increasingly harsh debates regarding social welfare, which, in recent years, has been discussed with an increasingly critical tone (Dencker-Larsen \& Lundberg 2016). Questions are being raised about the willingness and obligation of social security recipients to work and to contribute to the common good, as well as about what it means to be poor in an affluent society. A life spent on social security brings with it stigma and social exclusion (Järvinen \& Mik-Meyer, 2003; Mik-Meyer \& Villadsen, 2013), and it may add to the suffering of some of the most vulnerable people in the welfare state. As argued by Danish anthropologist Eva Gulløv (2011):

$[\ldots]$ to fare well through life is connected to culturally specific expectations of how to be and what to become. It also encompasses designs and prescriptions of how to fare well that not only address material concerns but equally concern ideas and values, performative requirements and social judgements. In other words welfare calls for behavior that corresponds to the demands and expectations of a person's cultural and social surroundings (p. 22).

Recognising the subtle ways in which people negotiate their self-worth with reference to the established normality of middle-classness in everyday occurrences or remarks, as exemplified by the conversation described above, may enrich our understanding of the practical and moral implications of living lives that diverge from middle-classness, and it could perhaps also remind us of the multiplicities of lives lived in what is considered to be egalitarian Scandinavia. 


\section{Concluding Discussion - Suffering in a Welfare Society}

The lives of Johnny and Jasmin, although distinct and subjective, exemplify some of the challenges associated with living lives that diverge from 'in-between middle-classness'. In their own ways, they exemplify how the suffering experienced by people living on the margins of the welfare state can be seen as conditioned by the complexities of equal worth, expectations to and from the state, morality and shame. Moreover, they add to our understanding of how the practice of everyday life in Denmark is marked by an obligation to take on social responsibility for preserving the common good, as established most prominently through participation in the workforce. The obligations related to living in a welfare society may hence be considered as a means of establishing deservingness and perhaps even belonging, a situation that naturally brings with it notions of othering and exclusion of those who do not (or cannot) fulfil such obligations.

This article has offered examples of the different ways in which the socially marginalised are impacted by the political shifts and economic transformations of a state characterised by competing and contradictory forces (Bourdieu, 1998, 1999). Without taking our conclusions to the same length as those of Waquant (2009), who argued that recent transformations in Western democracies have recalibrated the structures of power in such a way as to reduce the legal system to one of many avenues through which precarious groups of people are managed, we add to the literature that exposes the increasing levels of uncertainty imposed on marginalised populations by welfare institutions and governing bodies (see also Mik-Meyer \& Villadsen, 2013; Wilkinson \& Kleinman, 2009). Following the approach of Gullestad (1992, p. 195) and other Scandinavian observers, we suggest that oppression and exploitation are now less open, although they are practiced in much more subtle and indirect (even unconscious) ways, particularly in Scandinavia, and that recent transformations in the welfare state have resulted in a political and cultural climate in which the existence of poverty and suffering is subject to discussion and even questioning. As argued by Weber (1920), and also recently explored in contemporary settings by Wilkinson and Kleinman (2016), regulation, rationalisation and the drive towards more effective modes of government are partly rooted in the struggle to relieve our pain and suffering (Wilkinson \& Kleinman, 2016, p. 138). It is possible that the existence and noble intent of the welfare state has rendered us oblivious to the existence of the diverse of conditions and life chances available to large groups of people within society, chances that are influenced and conditioned by the social and economic organisation and regulation (i.e. the right and left hands) of that very same welfare state. Weber's 
(1920) notorious conceptualisation of the bureaucratisation of the social order as an iron cage, in which people are trapped in systems based purely on teleological efficiency, rational calculation and control, most certainly springs to mind here.

Additionally, one aim of this article has been to empirically add to Gullestad's (1992) argument that the notion of sameness may in fact help to conceal hierarchical relations within society, partly due to how egalitarian contexts offer ways of conceptualising existing social dissimilarities. With the Danish egalitarian context serving as our point of departure, we have argued that ideals of imagined sameness, whereby people from different social classes cluster in the same areas, send their children to the same schools and pursue their social lives in familiar settings and situations, perhap blind us to the social differences that the welfare state was originally intended to reduce. With reference to the work of Bourdieu (1984), Danish citizens increasingly interact and surround themselves with people from similar social and cultural habitus and capital, resulting in the establishment of subtle social boundaries or what Gullestad (1992, pp. 165-182) termed symbolic fences. Raising a similar point but from a comparative perspective, we have suggested that people from different classes often orient themselves towards the ideals of egalitarianism, meaning that existing inequalities are rarely brought to our attention and are, in fact, often underplayed (Merrild, 2018). This could be reinforced by middle-class notions of independency, personal development, and the willingness and inclination to progress and evolve, which have now become core principles of the welfare state and its services (Bruun, Krøijer, \& Rytter, 2016, p. 23; Mik-Meyer \& Villadsen, 2013). Welfare policies can be seen to reflect an agenda of sameness, with the right to welfare being built less on an imagination of sameness than on an expectation of sameness, which consequently downplays the suffering often experienced by people who live socially disadvantaged and challenging lives. One consequence of this could be that the ideals of the welfare state have blinded us to the suffering of those who do not live up to the models of the in-between, middle-class way of being Danish that plays out within the very institutions and services constituting what we hold to be socially responsible for the welfare of the entire population.

\section{References}

Atkinson, P. (2015). For ethnography. London: SAGE.

Beskæftigelsesministeriet. (2013). Aftale om en reform af kontanthjælpssystemet - flere $i$ uddannelse og job [Agreement on reforming of the social security system]. 
Retrieved from https://bm.dk/media/6496/aftaletekst_kontanthjaelpsreformpdf.pdf.

Bourdieu, P. (1984). Distinction: A social critique of the judgement of taste. Cambridge, MA: Harvard University Press.

Bourdieu, P. (1998). Acts of resistance: Against the new myths of our time. Oxford: Polity Press.

Bourdieu, P. (Ed.). (1999). The weight of the world. Oxford: Polity Press.

Bruun, M. H. (2018). Social imaginaries and egalitarian practices in the era of neoliberalization. In S. Bendixsen, M. B. Bringslid, \& H. Vike (Eds.), Egalitarianism in Scandinavia: Historical and contemporary perspectives (pp. 135-156.). Bergen: University of Bergen. https://doi.org/10.1007/978-3-319$\underline{59791-1 \_6}$

Bruun, M. H., Krøijer, S., \& Rytter, M. (2016). Indledende perspektiver [Introductive perspectives]. Velfærdsstaten. Tidskriftet Antropologi [The Welfare State. Journal of Anthropology], 72(1), 11-37.

Chomsky, N. (1999). Profit over people. Neoliberalism and global order. New York, NY: Seven Stories Press.

Dencker-Larsen, S., \& Lundberg, K. G. (2016). Depicted welfare-recipient stereotypes in Norway and Denmark: A photo-elicitation study. Nordic Journal of Social Research, 7(1), 1-15. https://doi.org/10.7577/njsr.2098

Diderichsen, F., Andersen, I., \& Manuel, C. (2011). Ulighed i Sundhed - Arsager og Indsatser [Inequality in health: Causes and interventions]. Copenhagen: Sundhedsstyrelsen.

Faber, S. T., Prieur, A., Rosenlund, L., \& Skjøtt-Larsen, J. (2012). Det Skjulte Klassesamfund [The hidden class society]. Aarhus: Aarhus Universitetsforlag.

Faber, S. T. (2008). På Jagt Efter Klasse [Hunting for social class] (Unpublished doctoral dissertation). Department of Sociology and Social Work, University of Aalborg, Aalborg.

Gullestad, M. (1992). The art of social relations: Essays on culture, social action and everyday life in modern Norway. Oxford: Oxford University Press.

Gullestad, M. (2001). Likhetens Grenser [The boundaries of equality]. In H. Liden, M. Lien, \& H. Vike (Eds.), Likhetens Paradokser. Antropologiske Undersøkelser i Det Moderne Norge [The paradoxes or equality. Anthropological studies in modern day Norway] (pp. 32-67). Oslo: Univeritetsforlaget.

Gulløv, E. (2011). Welfare and self care: Institutionalized visions for a good life in Danish day-care centres. Anthropology in Action, 18(3), 21-32. https://doi.org/10.3167/aia.2011.180303

Harvey, D. (2007). A brief history of neoliberalism. Oxford: Oxford University Press.

Hedegaard, T. F. (2016). Neo-liberalism and the Nordic welfare model: A study of the liberal alliance and ideological adaptation in Denmark. Nordic Journal of Social Research, 7(0), 16-30. https://doi.org/10.7577/njsr.2099

Järvinen, M., \& Mik-Meyer, N. (Eds.). (2003). At Skabe En Klient. Institutionelle Identiteter $i$ Socialt Arbejde [The making of a client. Institutionalized identities in social work]. Copenhagen: Hans Reitzels Forlag.

Jenkins, R. (2012). Being Danish. Paradoxes of identities in everyday life (2nd ed.). Copenhagen: Museum Tusculanum Press. 
Jöhncke, S. (2011). Integrating Denmark: The welfare state as a national(ist) accomplishment. In K. Fog Olwig \& K. Pæregaard (Eds.), The question of integration. Immigration, exclusion and the Danish welfare state. Newcastle Upon Tyne: Cambridge Scholars Publishing.

Katz, S. (2000). Busy bodies: Activities, aging, and the management of everyday life. Journal of Aging Studies, 14(2), 135-152. https://doi.org/10.1016/S08904065(00)80008-0

Lamb, S. (2014). Permanent personhood or meaningful decline? Toward a critical anthropology of successful aging. Journal of Aging Studies, 29, 41-52. https://doi.org/10.1016/j.jaging.2013.12.006

Langer, S., \& Højlund, S. (2011). An anthropology of welfare: Journeying towards the good life. Anthropology in Action, 18(3), 1-9. https://doi.org/10.3167/aia.2011.180301

Liden, H., Lien, M., \& Vike, H. (Eds.). (2001). Likhetens Paradokser. Antropologiske Undersøkelser i Det Moderne Norge [The paradoxes or equality. Anthropological studies in modern day Norway]. Oslo: Univeritetsforlaget.

Linnet, J. T. (2011). Money can't buy me 'hygge': Danish middle-class consumption, egalitarianism, and the sanctity of inner space. Social Analysis, 55(2), 21-44 https://doi.org/10.3167/sa.2011.550202

Ludvigsen, B. H. (2016). Når ÆEldre Mennesker Bliver Gamle: Betydningen Af Velfærdsstaten Og Medborgerskabet [When aging people get old: The meaning of the welfare state and citizenship]. Tidskriftet Antropologi [Journal of Anthropology], 73(2), 89-110.

Merrild, CH. (2015) Parallel Lives. (Unpublished doctoral dissertation). Department of Health, Aarhus University, Aarhus.

Merrild, C. H. (2018) Social differences in health as a challenge to the Danish welfare state, in Bendixsen, Bringslid and Vike (eds) Egalitarianism in Scandinavia: Historical and Contemporary Perspectives. Palgrave. Pp: 181 -200. https://doi.org/10.1007/978-3-319-59791-1_8

Merrild, C. H. and Andersen, R. S. (2019). Disengaging with the Cancerous Body. HEALTH, E-pub ahead of print. https://doi.org/10.1177/1363459319848049

Mik-Meyer, N., \& Villadsen, K. (2013). Power and welfare. Understanding citizens' encounters with state welfare. Oxford: Routledge. https://doi.org/10.4324/9780203113370

Offersen, S. M. H. (2016). Aiming for the ordinary (Unpublished doctoral dissertation). Department of Health, Aarhus University, Aarhus.

Olsen, L., Ploug, N., Andersen, L., \& Juul, J. S. (2012). Det Danske Klassesamfund [The hidden class society]. Copenhagen: Gyldendal.

Pedersen, O. K. (2011). Konkurrencestaten [The competition state]. Copenhagen: Hans Reizels.

Rytter, M. (2018). Made in Denmark: Refugees, integration and the self-dependent society. Anthropology Today, 34(3), 12-15. https://doi.org/10.1111/14678322.12433

Spradley, J. P. (1979). The ethnographic interview. Long Grove, IL: Waveland Press.

Wacquant, L. (2009). Punishing the poor: The neoliberal government of social insecurity. Durham, NC: Duke University Press.

Weber, M. (1920). The Protestant Ethic and the Spirit of Capitalism. Oxford: Oxford University Press. 
Wilkinson, I., \& Kleinman, A. (2016). A passion for society. How we think about human suffering. Berkeley, CA: University of California Press. https://doi.org/10.1525/california/9780520287228.001.0001 